University of Nebraska - Lincoln

DigitalCommons@University of Nebraska - Lincoln

1996

\title{
Approximation of Biodegradation Rate Constants for Monoaromatic Hydrocarbons (BTEX) in Ground Water
}

Todd Weidemeier

Matthew Swanson

John Wilson

Donald Kampbell

Ross Miller

See next page for additional authors

Follow this and additional works at: https://digitalcommons.unl.edu/usepapapers

Part of the Civil and Environmental Engineering Commons

Weidemeier, Todd; Swanson, Matthew; Wilson, John; Kampbell, Donald; Miller, Ross; and Hansen, Jerry, "Approximation of Biodegradation Rate Constants for Monoaromatic Hydrocarbons (BTEX) in Ground Water" (1996). U.S. Environmental Protection Agency Papers. 26.

https://digitalcommons.unl.edu/usepapapers/26

This Article is brought to you for free and open access by the U.S. Environmental Protection Agency at DigitalCommons@University of Nebraska - Lincoln. It has been accepted for inclusion in U.S. Environmental Protection Agency Papers by an authorized administrator of DigitalCommons@University of Nebraska - Lincoln. 


\section{Authors}

Todd Weidemeier, Matthew Swanson, John Wilson, Donald Kampbell, Ross Miller, and Jerry Hansen 


\title{
dation Rate Constants for Monoaromatic Hydrocarbons (BTEX) in Ground Water
}

\author{
by Todd H. Wiedemeier, Matthew A. Swanson, John T. Wilson, Donald H. Kampbell, Ross N. Miller,
} and Jerry E. Hansen

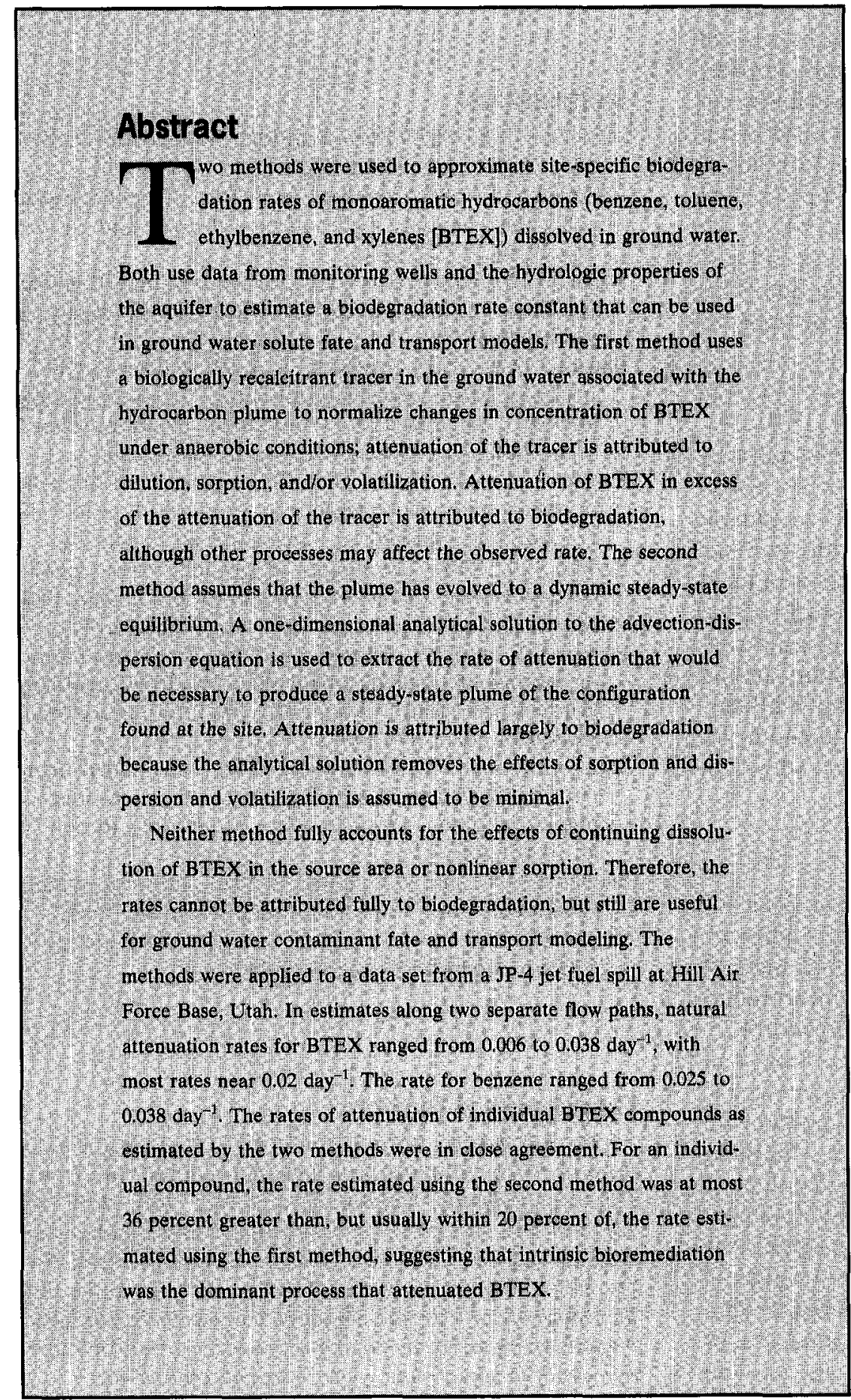

Pages 186-194

\section{Introduction}

As a management strategy, intrinsic remediation is gaining increased acceptance for use at sites contaminated with petroleum products. "Intrinsic remediation" refers to a management strategy that relies on natural attenuation mechanisms to remediate contaminants dissolved in ground water and to control receptor exposure risks associated with contaminants in the subsurface. "Natural attenuation" refers to the actual physical, chemical, and biological processes that facilitate intrinsic remediation. Mechanisms for natural attenuation of fuel hydrocarbons include advection, dispersion, dilution from recharge, sorption, volatilization, and biodegradation. Of these processes, biodegradation is the only mechanism working to transform contaminants into innocuous byproducts. Intrinsic bioremediation occurs when indigenous microorganisms work to bring about a reduction in the total mass of contamination in the subsurface without the addition of nutrients. Patterns and rates of intrinsic remediation can vary markedly from site to site depending upon governing physical and chemical processes.

At sites where petroleum products (e.g., gasoline, jet fuel, or diesel fuel) have been released and contribute to ground water contamination, many hydrocarbon compounds will partition into ground water; however, benzene, toluene, ethylbenzene, and xylene (BTEX) are generally the focus of site cleanup actions due to regulatory or 
risk concerns. In addition, as shown by the work of Smith et al. (1981), Bruce et al. (1991), and Cline et al. (1991), despite making up no more than 20 percent of the mass of fuel mixtures, BTEX compounds account for 82 percent of the dissolved compounds that partition from fresh JP-4 jet fuel into ground water and at least 98 percent of the dissolved compounds that partition from fresh gasoline into ground water. Therefore, understanding and quantifying the natural attenuation of the BTEX compounds is often the focus of site remediation for risk reduction.

BTEX in ground water may be attenuated through the processes of dispersion, dilution from recharge, sorption, volatilization, and biodegradation. Abiotic chemical transformation of BTEX compounds in ground water is not an important process, and volatilization is not likely to remove significant amounts of dissolved volatiles, as shown by Chiang et al. (1989). In most hydrogeologic systems, biodegradation is the most important process that removes BTEX from ground water. BTEX biodegradation processes in ground water include aerobic respiration, denitrification, iron or manganese reduction, sulfate reduction, and methanogenesis (Jamison et al. 1975; Atlas 1981, 1984, and 1988; Young 1984; Bartha 1986; Wilson et al. 1986 and 1990; Barker et al. 1987; Baedecker et al. 1988; Lee 1988; Chiang et al. 1989; Cozzarelli et al. 1990; Leahy and Colewell 1990; Alvarez and Vogel 1991; Evans et al. 1991a and 1991b; Edwards et al. 1992; Edwards and Grbic-Galic 1992; Thierrin et al. 1993; Davis et al. 1994; Lovley et al. 1995). The patterns and rates of intrinsic remediation can vary markedly from site to site, depending upon the relative importance of the various processes.

Three lines of evidence have been used to document intrinsic bioremediation: (1) documented loss of contaminants at the field scale; (2) chemical and geochemical analytical data, including accumulation in ground water of the intermediates and by-products of anaerobic metabolism of BTEX, and the depletion of electron acceptor concentrations in ground water; and (3) microbiological laboratory data, such as the results of microcosm studies, plate counts, or cultures.

The first line of evidence requires a statistically significant historical data base resulting from several sampling efforts. Often, historical data are not available. Microbiological laboratory methods, such as microcosm studies, are expensive and time consuming. Moreover, biodegradation rates determined from individual microcosms may not be applicable throughout the plume (i.e., at the field scale). Therefore, under the time and budget constraints of most site investigations, chemical and geochemical data often play an important role in describing intrinsic bioremediation processes and quantifying intrinsic bioremediation rates, especially at the field scale.

To evaluate the contribution of natural attenuation to the management of risk associated with a release of petroleum hydrocarbons, it often is necessary to calculate site-specific biodegradation rates, particularly if ground water solute fate and transport modeling is part of the assessment. A site-specific biodegradation rate approximated using one or both of the methods presented herein can be useful for modeling, as many numerical and analytical model codes allow the use of a first-order contaminant decay constant. Models incorporating a site-specific decay rate in conjunction with dispersivity and retardation coefficients may be employed for the following: to predict the future extent and concentration of dissolved contaminant plumes by modeling the effects of advection, dispersion, sorption, and biodegradation; to assess the possible exposure of potential downgradient receptors to contaminant concentrations that exceed levels intended to be protective of human health and the environment; and to provide technical support for selection of the intrinsic remediation option as the best remedial alternative, as appropriate.

This paper compares two independent methods that may be used to approximate site-specific rates of biodegradation using monitoring well data and hydrologic properties of the aquifer. The first method involves the use of a tracer (1,3,5-trimethylbenzene) that sorbs more strongly than the BTEX compounds, is less volatile than the BTEX compounds, and is recalcitrant to anaerobic biodegradation at many sites. Attenuation of the tracer at a site can be attributed to dilution, sorption, or volatilization. Attenuation of BTEX compounds in excess of the attenuation of the tracer cannot be attributed to dilution, sorption, and/or volatilization. Changes in the concentration of the conservative tracer are used to correct for changes in the concentration of contaminants caused by the effects of dispersion, dilution from recharge, volatilization, and sorption. The corrected concentrations reveal the contribution of biodegradation, along with the effects of continuing source dissolution and any additional (nonlinear) sorption that may occur in the contaminant plume and the source area.

The second method, proposed by Buscheck and Alcantar (1995), assumes that the plume has evolved to the point that it is being destroyed by natural attenuation as rapidly as it is being produced by dissolution of soluble hydrocarbons from the fuel spill. In this situation, the plume has reached a dynamic steady-state equilibrium. Buscheck and Alcantar (1995) apply a one-dimensional analytical solution (Bear 1979) to interpret the steady-state configuration of the contaminant plume along a flow path. By removing the effects of dispersion and sorption, their analysis extracts an approximate rate of biodegradation that would be necessary to produce a steady-state plume of the configuration actually found at the site.

Neither method estimates a true biodegradation rate because they do not account for some of the processes affecting plume formation and attenuation. For example, unless the contaminant source has been removed completely, contaminants will continue to enter ground water due to direct dissolution into ground water or dissolution into infiltrating precipitation. Thus, without accounting for the mass entering the system, one is prevented from determining a true biodegradation rate, 
even if the effects of sorption, dispersion, dilution, and/ or volatilization are removed. In addition, if background measurements of aquifer organic carbon are used to calculate retardation factors (assuming linear sorption) for the contaminants of interest, any nonlinear sorption or desorption within the plume and source area is not accounted for. Another factor preventing calculation of a true biodegradation rate is that the tracer method does not account for the loss of mass due to aerobic biodegradation, and the method of Buscheck and Alcantar (1995) does not account for mass lost to aerobic biodegradation at the upgradient margin of the plume.

The two methods were applied to data from the petroleum, oils, and lubricants (POL) bulk storage facility at Hill Air Force Base (AFB), Utah. Jet fuel (JP-4) was released into the soil and shallow ground water during fuel transfer operations at the POL facility.

\section{Site Description}

Hill AFB is located on a bench of the Wasatch Mountains on the edge of the Great Salt Lake Basin. Figure 1 shows the POL facility and the immediately adjacent area. Surface topography at the site slopes to the southwest. The shallow sediments underlying the site consist of light reddish-brown to dark gray, cohesive clayey silts to silty clays. This unit is 4 - to 15 -feet $(1.2$ to $4.6 \mathrm{~m})$ thick and is underlain by poorly to moderately sorted, yellowish-brown to reddish-brown, silty fine-grained sands that coarsen downward into a 3- to 22-foot-thick $(0.9$ to $6.7 \mathrm{~m})$ sequence of moderately sorted, mediumto coarse-grained sands. Underlying the sands is a sequence of competent, thinly interbedded clay to silty clay and fine- to very fine-grained, clayey sand and silt of unknown thickness. This sequence of interbedded clay and fine-grained sand and silt acts as an effective barrier to the downward migration of water and contaminants.

The water table aquifer is present in the mediumto coarse-grained sands described above, with the water table present between 5 and 20 feet $(1.5$ and $6.1 \mathrm{~m})$ below ground surface. Ground water flow is to the southwest with an average gradient of 0.046 foot per foot $(0.046 \mathrm{~m} / \mathrm{m})$. Available data suggest that there is almost no seasonal variation in ground water flow direction or gradient at the site. Based on slug tests and pumping tests, the average hydraulic conductivity for the medium- to coarse-grained sands of the shallow saturated zone is 0.0084 centimeter per second. Effective porosity for the types of sediments observed in the saturated zone ranges from 0.15 to 0.35 (Domenico and Schwartz 1990). Assuming an effective porosity of 0.25 , the average advective ground water velocity is $4.4 \mathrm{ft} /$ day $(1.34 \mathrm{~m} /$ day $)$ or approximately $1600 \mathrm{ft} /$ year ( $488 \mathrm{~m} /$ year).

The concentration of total organic carbon (TOC) measured in four soil samples ranged from 0.069 to 0.094 percent. Because of the low TOC concentration and clay mineral content observed in the shallow saturated zone, retardation of the BTEX compounds is not likely

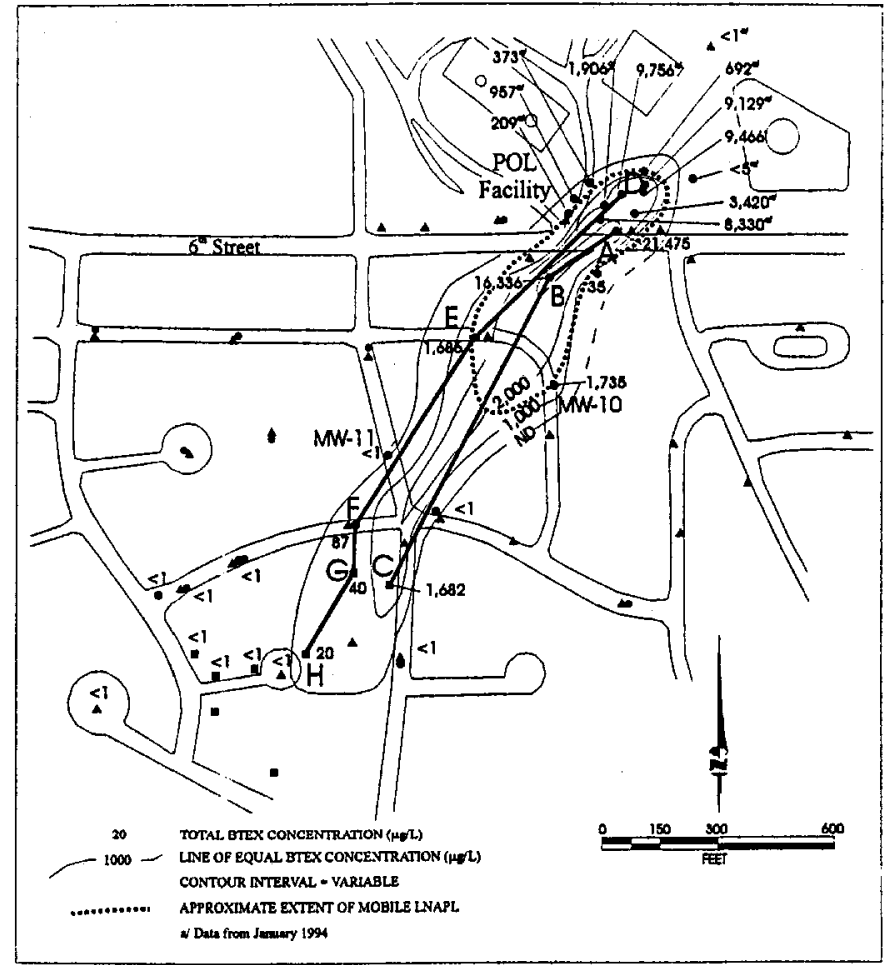

Figure 1. Total BTEX isopleth map.

to be an important process affecting solute transport at this site.

General ambient ground water geochemistry at the site is conducive to intrinsic bioremediation. Total alkalinity at the site is fairly high, ranging from 349 to 959 milligrams per liter as calcium carbonate. This amount of alkalinity is sufficient to buffer potential changes in $\mathrm{pH}$ caused by biological production of carbon dioxide. Ground water $\mathrm{pH}$ at the POL facility ranges from 6.3 to 8.3 standard units. The average temperature of ground water is 64 degrees Fahrenheit (18 degrees Celsius). The oxidation/reduction potential (ORP) at the POL ranges from $274 \mathrm{mV}$ to $-190 \mathrm{mV}$. Areas at the site with low ORPs coincide with areas of BTEX contamination and areas with low concentrations of dissolved oxygen, nitrate, and sulfate and elevated concentrations of iron (II) and methane. This is strong evidence that dissolved BTEX at the site is subjected to a variety of biodegradation processes, including aerobic respiration, denitrification, iron reduction, sulfate reduction, and methanogenesis.

Figure 1 shows the approximate extent of mobile light nonaqueous phase liquid (LNAPL) at the site. This LNAPL is composed of weathered JP-4 released from the POL facility and is up to 4-feet $(1.2 \mathrm{~m})$ thick. Measured residual total BTEX concentrations in soil decrease rapidly outside the area of mobile LNAPL contamination. The highest dissolved BTEX concentration observed in ground water at the site was $21,000 \mu \mathrm{g} / \mathrm{L}$. Figure 1 shows the distribution of total BTEX dissolved in ground water in July 1994. BTEX contamination is migrating to the southwest, in the direction of ground water flow. Figure 1 includes data collected from 12 monitoring wells in the source area north of 6th Street in January 1994. These 
wells cover a small area relative to the extent of the dissolved plume, and these data represent the only data collected in this area in 1994. Data collection points shown on the map with no data represent locations sampled during other sampling events. Dissolved BTEX concentrations observed at these locations during previous and subsequent sampling events were taken into consideration when preparing Figure 1.

\section{Approximate Biodegradation Rate Constant Calculation Using a Conservative Tracer}

To determine approximate biodegradation rate constants, measured concentrations of dissolved BTEX were corrected for the effects of dispersion, dilution from recharge, volatilization, and sorption using a tracer. One tracer that has proved useful in some, but not all, ground water environments is trimethylbenzene (TMB). The three isomers of this compound $(1,2,3-$ TMB, 1,2,4-TMB, and 1,3,5-TMB) have Henry's law constants and soil sorption coefficients similar to (although somewhat higher than) those of the BTEX compounds (Table 1). Also, the TMB isomers generally are present in sufficient quantities in fuel mixtures to be readily detectable in ground water in contact with a fuel spill. Finally, they often are recalcitrant to biodegradation in the anaerobic portion of a plume; 1,3,5-TMB was found to be the most recalcitrant TMB isomer at the POL site and was used in the following calculations. Other compounds of potential use as conservative tracers are the tetramethylbenzene isomers, provided they are present in concentrations that are detectable throughout most of the plume.

The corrected concentration of a compound is the concentration of the compound that would be expected at one point (B) located downgradient from another point (A) after correcting for the effects of dispersion, dilution from recharge, volatilization, and sorption between points $\mathrm{A}$ and $\mathrm{B}$. One method of calculating the corrected concentration (Wilson et al. 1994; Wiedemeier et al. 1995a) is given by:

$C_{B, \text { corr }}=C_{B}\left(\frac{T_{M B}}{T_{A}}\right)$

where

$\mathrm{C}_{\mathrm{B}, \mathrm{corr}}=$ corrected concentration of compound of interest at Point $\mathrm{B}$

$\mathrm{C}_{\mathrm{B}}=$ measured concentration of compound of interest at Point $\mathrm{B}$

$\mathrm{TMB}_{\mathrm{A}}=$ measured concentration of trimethylbenzene at Point A

$\mathrm{TMB}_{\mathrm{B}}=$ measured concentration of trimethylbenzene at Point B.

Because trimethylbenzene is slightly more hydrophobic than BTEX, and therefore has a higher soil sorption coefficient, there likely is preferential sorption of TMB relative to the BTEX compounds. In addition, TMB may not be entirely recalcitrant under some anaerobic conditions, and it appears to degrade rapidly under aerobic conditions. The degree of recalcitrance

\section{Table 1}

Soil Sorption Coefficients and Henry's Law Constants for BTEX and TMB

\begin{tabular}{|c|c|c|}
\hline Compound & $\begin{array}{c}\text { Soil Sorption } \\
\text { Coefficient } \\
{\left[\mathrm{K}_{\mathrm{oc}},(\mathrm{L} / \mathrm{Kg})\right]^{\mathrm{a}}}\end{array}$ & $\begin{array}{c}\text { Henry's Law } \\
\text { Constant } \\
\left(\operatorname{atm}-\mathbf{m}^{3} / \mathbf{m o l}\right)^{\mathrm{a}}\end{array}$ \\
\hline Benzene & 79 & 0.005 \\
\hline Toluene & 190 & 0.007 \\
\hline Ethylbenzene & 468 & 0.007 \\
\hline Xylene $^{\mathrm{b}}$ & 400 & 0.006 \\
\hline 1,3,5-trimethylbenzene & 676 & 0.006 \\
\hline Trimethylbenzene $^{b}$ & 800 & 0.007 \\
\hline
\end{tabular}

of TMB is site specific, and the use of this compound as a tracer must be evaluated on a case-by-case basis. However, if any TMB mass is lost to the processes of biodegradation or preferential sorption, Equation 1 is conservative because the calculated mass losses and the attenuation rate constants calculated on the basis of those losses will be lower than the actual losses and attenuation rates.

Seven points along two flow paths parallel to the direction of ground water flow were chosen for comparison of corrected and observed BTEX concentrations (Figure 1). Table 2 presents BTEX and TMB data for these points. One flow path (points A, B, and C) coincides with the highest observed BTEX concentrations, and thus delineates the centerline of the dissolved BTEX plume. The other flow path (points D, E, F, G, and $\mathrm{H}$ ) is located off the centerline of the plume, closer to the plume periphery. Table 2 also shows tracer-corrected BTEX concentrations. In conjunction with the aforementioned geochemical data, the calculations presented in this table imply that biodegradation of BTEX compounds is an important natural attenuation process at this site.

An approximate first-order biodegradation rate can be calculated if it can be shown that the corrected contaminant distribution approximates a distribution resulting from a first-order process. Figure 2 is a $\log$ linear plot of tracer-corrected dissolved BTEX concentrations vs. downgradient travel time along the centerline of the ground water flow path (flow path $A B C$ ). Figure 3 is a log-linear plot of tracer-corrected dissolved BTEX concentrations vs. downgradient travel time along the flow path DEFGH. Figures 2 and 3 show that natural attenuation (largely due to biodegradation) along these flow paths approximates a first-order process.

First-order decay is described by the relationship:

$\mathrm{C}=\mathrm{C}_{\mathrm{o}} \mathrm{e}^{-\mathrm{kt}}$

where

$\mathrm{C}=$ contaminant concentration at time $\mathrm{t}$

$\mathrm{C}_{\mathrm{o}}=$ initial contaminant concentration

$\mathrm{k}$ = first-order decay constant (total attenuation rate). 
Table 2

Benzene, Toluene, Ethylbenzene, Xylene, and TMB Concentrations

\begin{tabular}{|c|c|c|c|c|c|c|c|c|c|c|c|c|c|}
\hline $\begin{array}{l}\text { Sample } \\
\text { Location }\end{array}$ & $\begin{array}{c}\text { Travel } \\
\text { Distance } \\
\text { (m) }\end{array}$ & $\begin{array}{l}\text { Travel } \\
\text { Time } \\
\text { (days) }\end{array}$ & $\begin{array}{c}\text { 1,3,5-TMB } \\
(\mu g / L)\end{array}$ & $\begin{array}{c}\text { Benzene } \\
(\mu \mathrm{g} / \mathrm{L})\end{array}$ & $\begin{array}{c}\text { TMB- } \\
\text { Corrected } \\
\text { Benzene } \\
(\mu g / L)\end{array}$ & $\begin{array}{c}\text { Toluene } \\
(\mu \mathrm{g} / \mathrm{L})\end{array}$ & $\begin{array}{c}\text { TMB- } \\
\text { Corrected } \\
\text { Toluene } \\
(\mu \mathrm{g} / \mathrm{L})\end{array}$ & $\begin{array}{c}\text { Ethyl- } \\
\text { benzene } \\
(\mu g / L)\end{array}$ & $\begin{array}{c}\text { TMB- } \\
\text { Corrected } \\
\text { Ethylben- } \\
\text { zene } \\
(\mu \mathrm{g} / \mathrm{L})\end{array}$ & $\begin{array}{l}\text { Xylene } \\
(\mu g / L)\end{array}$ & $\begin{array}{c}\text { TMB- } \\
\text { Corrected } \\
\text { Xylene } \\
(\mu \mathrm{g} / \mathrm{L})\end{array}$ & $\begin{array}{c}\text { Total } \\
\text { BTEX } \\
(\mu \mathrm{g} / \mathrm{L})\end{array}$ & $\begin{array}{c}\text { TMB- } \\
\text { Corrected } \\
\text { Total } \\
\text { BTEX } \\
(\mu g / L)\end{array}$ \\
\hline \multicolumn{14}{|c|}{ Flow Path ABC (Plume Centerline) } \\
\hline A & 0 & 0 & 417 & 5600 & 5600 & 5870 & 5870 & 955 & 955 & 9050 & 9050 & 21,475 & 21,475 \\
\hline $\mathrm{B}^{\mathrm{a}}$ & 67 & 50 & 485 & 4260 & 4260 & 3910 & 3910 & 816 & 816 & 7350 & 7350 & 16,336 & 16,336 \\
\hline $\mathrm{C}$ & 335 & 250 & 396 & 6 & 7 & 18 & 22 & 103 & 126 & 1555 & 1904 & 1682 & 2060 \\
\hline \multicolumn{14}{|c|}{ Flow Path DEFGH (Plume Periphery) } \\
\hline $\mathrm{D}$ & 0 & 0 & 650 & 941 & 941 & 2800 & 2800 & 505 & 505 & 5510 & 5510 & 9756 & 9756 \\
\hline $\mathrm{E}$ & 143 & 106 & 125 & 458 & $458^{\mathrm{b}}$ & 10 & 52 & 454 & $454^{b}$ & 765 & 3978 & 1686 & 4942 \\
\hline$F^{a}$ & 311 & 232 & 144 & 7 & 6 & 10 & 9 & 23 & 20 & 47 & 41 & 87 & 87 \\
\hline $\mathrm{G}$ & 341 & 254 & 78 & 0 & 0 & 0 & 0 & 4 & 7 & 36 & 66 & 73 & 135 \\
\hline $\begin{array}{l}\text { TMB con } \\
\text { decreases } \\
\text { Benzene } \\
\text { c } 1,3,5-\mathrm{TM}\end{array}$ & $\begin{array}{l}\text { ntrations i } \\
\text { BTEX co } \\
\text { dethylben }\end{array}$ & $\begin{array}{l}\text { ased slig } \\
\text { atrations } \\
\text { are mo }\end{array}$ & $\begin{array}{l}\text { y between } p \\
\text { re due entire } \\
\text { recalcitrant }\end{array}$ & $\begin{array}{l}\text { oints } A \text { and } \\
\text { ly to biodeg } \\
\text { than } 1,3,5-T \\
\text { ad } H \text {. }\end{array}$ & $\begin{array}{l}B \text { and poin } \\
\text { radation. } \\
M B \text { betwee }\end{array}$ & $\begin{array}{l}\text { and } F \\
\text { ints } D \text { ? }\end{array}$ & suggests the & & entirely $\mathrm{r}$ & itrant & en these & and & observed \\
\hline
\end{tabular}

Substituting the TMB-corrected concentration, $\mathrm{C}_{\mathrm{B}, \mathrm{corr}}$ at a downgradient point (B) for $\mathrm{C}$ in Equation 2, and the measured concentration $\mathrm{C}_{\mathrm{A}}$ at an upgradient point (A) for $\mathrm{C}_{\mathrm{o}}$, this relationship becomes:

$\mathrm{C}_{\mathrm{B}, \text { corr }}=\mathrm{C}_{\mathrm{A}} \mathrm{e}^{-\lambda t}$

where

$\mathrm{C}_{\mathrm{B}, \mathrm{corr}}=\mathrm{TMB}$-corrected contaminant concentration at time $t$ at downgradient point $B$

$\mathrm{C}_{\mathrm{A}}=$ measured contaminant concentration at upgradient point $\mathrm{A}$

$\lambda=$ approximate first-order biodegradation constant.

Whereas the decay constant in Equation 2 describes the overall attenuation rate due to advection, dispersion, sorption, dilution from recharge, volatilization, and biodegradation, the decay constant in Equation 3 can be attributed largely to biological attenuation. However, as noted before, this is not a true biodegradation rate.

The travel time, $t$, between two points is given by:

$\mathrm{t}=\frac{\mathrm{x}}{\mathrm{v}_{\mathrm{c}}}$

where

$\mathrm{t}=$ travel time between two points

$\mathrm{x}=$ distance between two points

$v_{c}=$ retarded solute velocity (where applicable).

Use of the retarded solute velocity is appropriate where the organic carbon content of the aquifer matrix is sufficient to retard the migration of dissolved BTEX compounds. However, in some cases (such as at Hill AFB), retardation of the plume will be so limited that use of the advective velocity will approximate the retarded velocity. Background aquifer organic carbon concentrations may be used to calculate a retardation

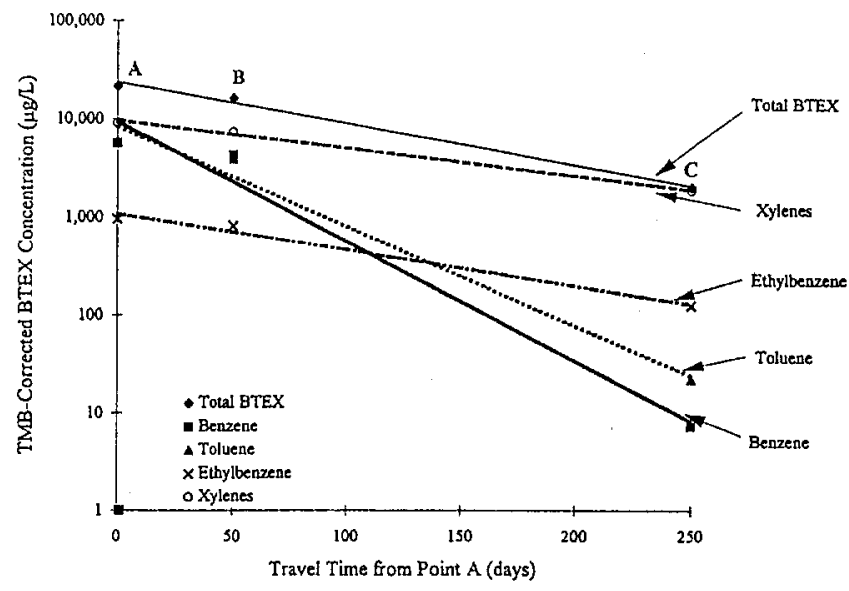

Figure 2. Plot of trimethylbenzene-corrected BTEX concentration vs. travel time along flow path $A B C$.

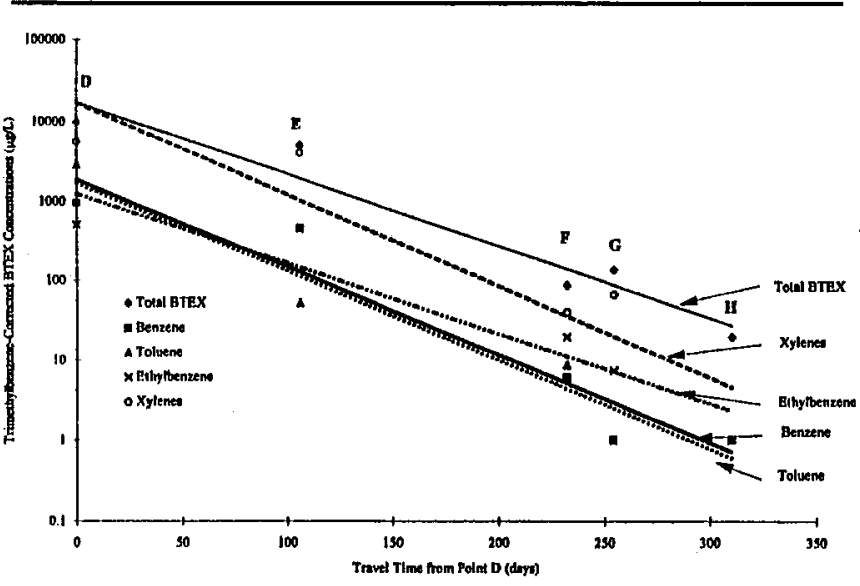

Figure 3. Plot of trimethylbenzene-corrected BTEX concentration vs. travel time along flow path DEFGH.

factor and a retarded solute velocity, but this may not accurately represent the solute velocity in the plume interior. However, as long as the retarded solute velocity is overestimated (i.e., retardation is underestimated), 
Table 3

Results of Exponential Regression Analyses

\begin{tabular}{|c|c|c|c|c|c|c|c|c|}
\hline \multirow[b]{2}{*}{ Compound } & \multicolumn{4}{|c|}{ Results Using Trimethylbenzene ${ }^{a}$} & \multicolumn{4}{|c|}{ Results Using Method of Buscheck and Alcantar } \\
\hline & $\begin{array}{l}\text { Calculated y } \\
\text { Intercept (b) }\end{array}$ & $\begin{array}{l}\text { Slope } \\
\text { (m) }\end{array}$ & $\mathbf{R}^{2}$ & $\begin{array}{c}\text { Approximated Biodegra- } \\
\text { dation Rate Constant } \\
\left(\lambda, \text { day }^{-1}\right)^{\mathbf{c}}\end{array}$ & $\begin{array}{l}\text { Calculated y } \\
\text { Intercept (b) }\end{array}$ & $\begin{array}{c}\text { Slope } \\
(\mathbf{m}=\mathbf{k} / \mathbf{v})\end{array}$ & $\mathbf{R}^{2}$ & $\begin{array}{l}\text { Approximated Biodegra- } \\
\text { dation Rate Constant } \\
\left(\lambda, \text { day }^{-1}\right)^{\mathbf{e}}\end{array}$ \\
\hline \multicolumn{9}{|c|}{ Flow Path ABC (Plume Centerline) } \\
\hline Benzene & 9249 & -0.028 & 0.98 & 0.028 & 9430 & -0.022 & 0.98 & 0.038 \\
\hline Toluene & 8229 & $-0,023$ & 0.98 & 0.023 & 8390 & -0.018 & 0.98 & 0.031 \\
\hline Ethylbenzene & 1075 & -0.009 & 0.99 & 0.009 & 1095 & -0.007 & 0.98 & 0.010 \\
\hline Xylene & 9508 & -0.006 & 0.99 & 0.006 & 9693 & -0.005 & 0.99 & 0.008 \\
\hline Total BTEX & 23,568 & -0.010 & 0.99 & 0.010 & 24,028 & -0.008 & 0.99 & 0.012 \\
\hline \multicolumn{9}{|c|}{ Flow Path DEFGH ${ }^{\text {b }}$ (Plume Periphery) } \\
\hline Benzene & 1872 & -0.025 & 0.92 & 0.025 & 1633 & -0.016 & 0.89 & 0.027 \\
\hline Toluene & 1696 & -0.026 & 0.95 & 0.026 & 908 & -0.017 & 0.78 & 0.029 \\
\hline Ethyibenzene & 1243 & -0.020 & 0.89 & 0.020 & 1122 & -0.015 & 0.89 & 0.024 \\
\hline Xylene & 17,126 & -0.027 & 0.87 & 0.027 & 5547 & -0.015 & 0.99 & 0.024 \\
\hline Total BTEX & 17,431 & -0.021 & 0.94 & 0.021 & 11,296 & -0.015 & 0.99 & 0.025 \\
\hline $\begin{array}{l}\text { "Gencral form } \\
\text { boint G not } \mathrm{u} \\
{ }^{\mathrm{c}} \lambda=\text { slope of } \\
{ }^{\mathrm{d}} \text { General form } \\
\text { " From Equatio }\end{array}$ & $\begin{array}{l}\text { ential relation } \\
\text { thylbenzene at } \\
\text { e. } \\
\text { ential relation }\end{array}$ & $y=b e^{n}$ & $\begin{array}{l}\text { re } y= \\
\text { thylbe } \\
\text { re } y=\end{array}$ & $\begin{array}{l}\text { neentration, } b=\text { calculated } \\
\text { ne is not recalcitrant bctwe } \\
\text { ncentration, } b=\text { calculated }\end{array}$ & ints $F$ and $G$. & (n) & 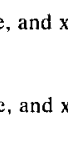 & $\begin{array}{l}\text { travel time. } \\
\text { distance downgradient. }\end{array}$ \\
\hline
\end{tabular}

the rate constant calculated using this method will be conservative (i.e., lower).

After the travel times between points were estimated and the BTEX concentrations were corrected, an exponential regression analysis was performed. Exponential regression was performed for each of the BTEX compounds and for total BTEX using the plots presented as Figures 2 and 3 . Table 3 presents the results of these regressions. The rate constants are within the range indicated in recent literature (Table 4). First-order rate constants calculated using TMB as a conservative tracer range from $0.006 \mathrm{day}^{-1}$ (xylene) to $0.028 \mathrm{day}^{-1}$ (benzene) along flow path $\mathrm{ABC}$, and range from 0.020 day $^{-1}$ (ethylbenzene) to $0.027 \mathrm{day}^{-1}$ (benzene) along flow path DEFGH.

\section{Approximate Biodegradation Rate Constant Calculation Using the Method of Buscheck and Alcantar (1995)}

Buscheck and Alcantar (1995) derive a relationship that allows calculation of approximate first-order biodegradation rate constants. An important assumption that must be made when using this method is that the contaminant plume has reached a steady-state configuration. This method involves coupling the regression of contaminant concentration (plotted on a logarithmic scale) vs. distance downgradient (plotted on a linear scale) to an analytical solution for one-dimensional, steady-state, contaminant transport that includes advection, dispersion, sorption, and biodegradation. The effects of volatilization on the dissolved BTEX plume are assumed to be negligible. For a steady-state plume,

\begin{tabular}{|c|c|}
\hline \multicolumn{2}{|c|}{$\begin{array}{c}\text { Table } 4 \\
\text { Representative First-Order } \\
\text { Biodegradation Rate Constants }\end{array}$} \\
\hline Reference & Biological Decay Rate $\left(\right.$ day $\left.^{-1}\right)$ \\
\hline $\begin{array}{l}\text { Chapelle (1994) } \\
\text { Wilson et al. (1994) } \\
\text { Stauffer et al. (1994) } \\
\text { MacIntyre et al. (1993) } \\
\text { MacIntyre et al. (1993) } \\
\text { Wilson et al. (1993) } \\
\text { Buscheck et al. (1993) }\end{array}$ & $\begin{array}{c}0.01^{\mathrm{a}} \\
0.19^{\mathrm{a}} \\
0.01^{\mathrm{b}} \text { to } 0.019^{\mathrm{c}} \\
0.01 \text { to } 0.02^{\mathrm{c}} \\
0.007 \text { to } 0.012^{\mathrm{b}} \\
0.0024 \text { to } 0.067^{\mathrm{a}} \\
0.001 \text { to } 0.01^{\mathrm{a}}\end{array}$ \\
\hline $\begin{array}{l}\text { a For total BTEX } \\
{ }^{\circ} \text { For benzene } \\
{ }^{c} \text { For xylene }\end{array}$ & \\
\hline
\end{tabular}

the first-order decay rate is given by (Buscheck and Alcantar 1995):

$\lambda=\frac{\mathrm{v}_{\mathrm{c}}}{4 \alpha_{\mathrm{x}}}\left(\left[1+2 \alpha_{\mathrm{x}}\left(\frac{\mathrm{k}}{\mathrm{v}_{\mathrm{x}}}\right)\right]^{2}-1\right)$

where

$\lambda=$ first-order biodegradation rate constant (approximate)

$\mathrm{v}_{\mathrm{c}}=$ retarded contaminant velocity in the $\mathrm{x}$-direction

$\alpha_{\mathrm{x}} \quad=$ dispersivity

$\mathrm{k} / \mathrm{v}_{\mathrm{x}}=$ slope of line formed by making a log-linear plot of contaminant concentration vs. distance downgradient along flow path.

Figure 4 shows the dissolved BTEX plume in August 1993, July 1994, and September 1995. On the basis of the calculated advective velocity of the ground water, 
the contaminant plume at Hill AFB should have migrated approximately 1450 feet ( $442 \mathrm{~m}$ ) downgradient between August 1993 and July 1994, and 1700 feet (518 m) downgradient between July 1994 and September 1995. Figure 4 shows that the dissolved BTEX plume has not migrated a significant distance downgradient from the position it occupied in 1993, suggesting that the dissolved BTEX plume has reached a steady-state configuration.

Figures 5 and 6 present log-linear plots of measured BTEX concentrations vs. distance downgradient along flow paths $\mathrm{ABC}$ and DEFGH, respectively. Table 2 presents the data that were used to construct these plots. Exponential regressions were completed for each of the BTEX compounds and for total BTEX along each flow path (Figures 5 and 6 ). The value of $\mathrm{k} / \mathrm{v}$ determined from the regression analysis is entered into Equation 5 and the approximate biodegradation rate constant, $\lambda$, is calculated. A longitudinal dispersivity of 50 feet $(15 \mathrm{~m})$ was estimated by using one-tenth of the distance between the spill source and the longitudinal centroid of the plume. This value of dispersivity is consistent with published literature values for these types of sediments. As noted previously, retardation is not important at the Hill AFB site, and the advective ground water velocity was used for these calculations. Table 3 presents the results of the regression analyses for this method.

First-order biodegradation rate constants approximated using the method of Buscheck and Alcantar (1995) range from $0.008 \mathrm{day}^{-1}$ (xylene) to $0.038 \mathrm{day}^{-1}$ (benzene) along flow path $\mathrm{ABC}$, and range from 0.024 day $^{-1}$ (xylene and ethylbenzene) to $0.029 \mathrm{day}^{-1}$ (toluene) along flow path DEFGH.

One additional source of error in this calculation is the use of an assumed dispersivity. However, a sensitivity analysis shows that the model is only slightly sensitive to changes in dispersivity. Increasing dispersivity results in higher calculated attenuation rates. For example, if the dispersivity is assumed to be 1 foot $(0.31 \mathrm{~m})$, the calculated attenuation rate for total BTEX along flow path DEFGH is 0.020 day $^{-1}$, and if the dispersivity is taken as 100 feet $(30.5 \mathrm{~m})$, the attenuation rate along DEFGH is $0.030 \mathrm{day}^{-1}$. Along flow path $\mathrm{ABC}$, the calculated attenuation rate for total BTEX is $0.011 \mathrm{day}^{-1}$ when dispersivity is 1 foot $(0.31 \mathrm{~m})$, and 0.013 day $^{-1}$ when dispersivity is 100 feet $(30.5 \mathrm{~m})$.

\section{Conclusions}

Table 3 shows that site-specific first-order biodegradation rate constants approximated using BTEX concentrations corrected using TMB as a tracer are remarkably consistent with the rate constants approximated using the method of Buscheck and Alcantar (1995). For all of the BTEX compounds, the rate constants calculated using a tracer are slightly less than those calculated using the method of Buscheck and Alcantar (1995). One reason for thi: is that tracer-corrected rate constants do not account for differential sorption or the fact that TMB is not entirely recalcitrant under anaerobic conditions. However, both of these factors make the TMB

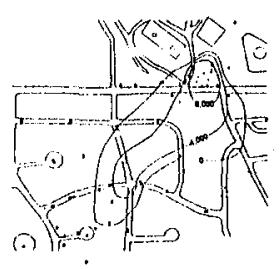

AUGUST 1993

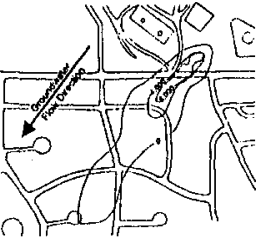

JULY 1994

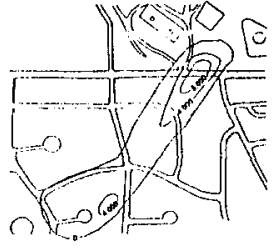

SEPTEMBER 1995

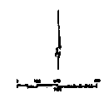

Figure 4. Dissolved BTEX plume at Hill AFB in 1993, 1994, and 1995.

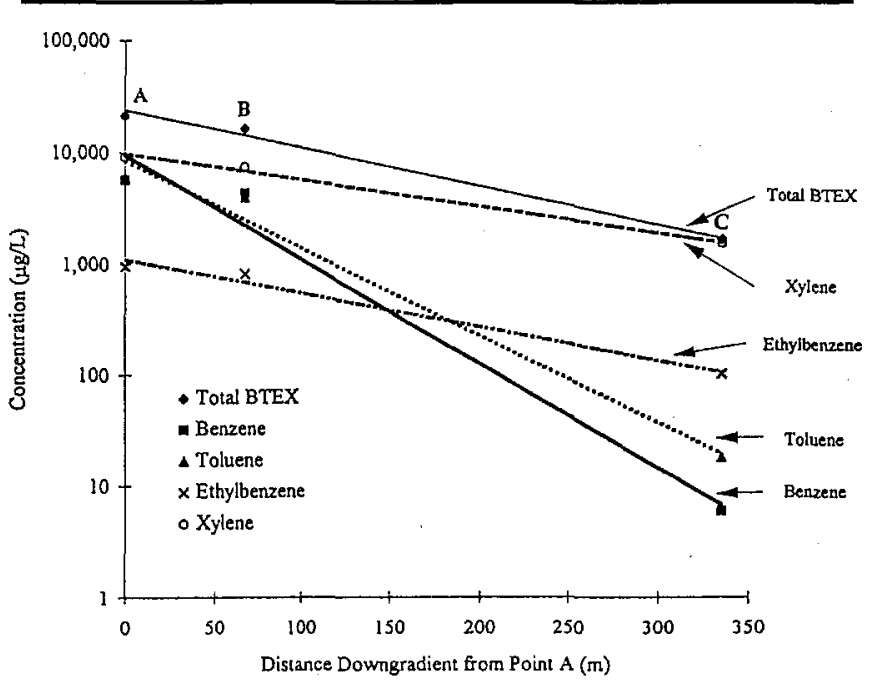

Figure 5. Plot of BTEX concentration vs. distance downgradient along flow path $A B C$.

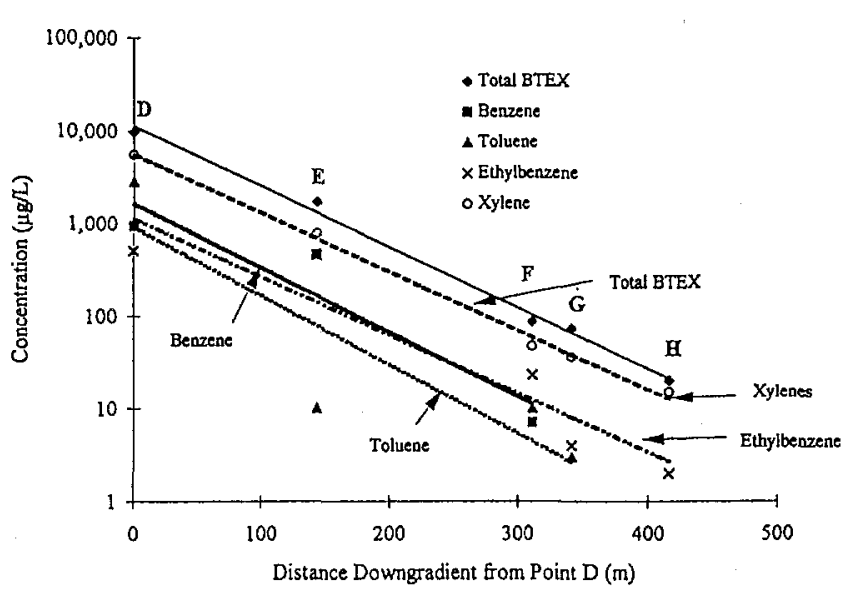

Figure 6. Plot of BTEX concentration vs. distance downgradient along flow path DEFGH.

results more conservative (i.e., a slower rate constant). In both cases, the biodegradation rates are approximate because continuing source dissolution and nonlinear sorption are not accounted for. Once calculated, these site-specific rates can be employed in analytical or numerical ground water contaminant fate and transport models to predict plume behavior, evaluate potential risks to downgradient receptors, and make site management decisions.

Sensitivity analyses suggest that dispersion has a 
small influence on the results of the calculations completed using the method of Buscheck and Alcantar (1995) for this site. The aquifer is overlain by a silty clay unit that should restrict recharge and limit volatilization. Furthermore, volatilization is generally not an important process acting to remove BTEX. For example, Chiang et al. (1989) used mass balance considerations to show that less than 5 percent of the mass of BTEX removed from ground water at a Michigan gas plant could be attributed to volatilization.

Approximate site-specific biodegradation rates calculated from the Hill AFB data are within the ranges published in recent literature (Table 4). Calculated degradation rates along the centerline of the Hill AFB plume (flow path $A B C$ ) generally are slower than those calculated along a flow path near the periphery of the plume (flow path DEFGH). This is likely due to the continuing introduction of dissolved BTEX in the vicinity of the source and the greater availability of electron acceptors near the margins of the BTEX plume.

Benzene degradation rates at Hill AFB were generally similar to the rates calculated for the other BTEX compounds. This is not consistent with experience at other sites where intrinsic bioremediation of BTEX has been documented. Barker et al. (1987), Cozzarelli et al. (1990 and 1994), and Wilson et al. (1993) found benzene to be more recalcitrant to biodegradation than the other BTEX compounds at the sites they studied. This suggests that pathways and patterns of BTEX biodegradation are site specific, as are the apparent rates of biodegradation. The fate of benzene may be controlled by the dominant terminal electron-accepting process. The dominant electron-accepting process at Hill AFB was sulfate reduction, accounting for 59 percent of the total expressed electron-accepting activity (Wiedemeier et al. 1995c). Methanogenesis accounted for 7 percent, iron reduction for 7 percent, denitrification for 21 percent, and aerobic respiration for 6 percent of the total expressed electron-accepting activity.

Where possible, both methods presented in this paper should be compared to evaluate the natural attenuation of BTEX in a plume. Use of this approach may not be appropriate at sites or in portions of a plume where the tracer is not biologically recalcitrant, or where the BTEX plume has not reached a steady-state configuration. If the plume has not reached a steady-state configuration, then tracer data can be used to provide a conservative estimate of biodegradation rates in the plume. If the tracer is not biologically recalcitrant and the plume is not stable, neither method is entirely appropriate. It may still be possible in this case to derive a rate constant using tracer-corrected data. However, the approach will likely produce unrealistically show rates and should not be used for transport calculations or modeling without a sensitivity analysis.

\section{References}

Alvarez, P.J.J., and T.M. Vogel. 1991. Substrate interactions of benzene, toluene, and para-xylene during microbial degradation by pure cultures and mixed culture aquifer slurries. Applied Environmental Microbiology 57, 2981-2985.
Atlas, R.M. 1981. Microbial degradation of petroleum hydrocarbons: An environmental perspective. Microbiological Reviews 45, no. 1: 180-209.

Atlas, R.M. 1984. Petroleum microbiology. New York: Macmillan Publishing Co.

Atlas, R.M. 1988. Microbiology: Fundamentals and applications. New York: Macmillan Publishing Co.

Baedecker, M.J., D.I. Siegel, P.C. Bennett, and I.M. Cozzarelli. 1988. The fate and effects of crude oil in a shallow aquifer: I. The distribution of chemical species and geochemical facies. In U.S. Geological Survey Toxic Substances Hydrology Program, Proceedings of the Technical Meeting, Phoenix, Arizona, September 26-30, 1988, ed. G.E. Mallard and S.E. Ragone, 13-20. Denver, Colorado: U.S. Geological Survey.

Barker, J.F., G.C. Patrick, and D. Major. 1987. Natural attenuation of aromatic hydrocarbons in a shallow sand aquifer. Ground Water Monitoring Review 7, no. 1: 64-71.

Bartha, R. 1986. Biotechnology of petroleum pollutant biodegradation. Microbial Ecology 12, 155-172.

Bear, J. 1979. Hydraulics of groundwater. New York: McGraw Hill.

Bruce, L., T. Miller, and B. Hockman. 1991. Solubility versus equilibrium saturation of gasoline compounds: A method to estimate fuel/water partition coefficient using solubility or $\mathrm{K}_{\mathrm{oc}}$. In Proceedings of the NWWA/API Conference on Petroleum Hydrocarbons in Ground Water, 571-582, by National Water Well Association. Dublin, Ohio: NWWA.

Buscheck, T.E., K.T. O'Reilly, and S.N. Nelson. 1993. Evaluation of intrinsic biodremediation at field sites. In Proceedings of the conference on petroleum hydrocarbons and organic chemicals in ground water: Prevention, detection, and restoration, 367-381, by National Ground Water Association. Dublin, Ohio: NGWA.

Buscheck, T.E., and C.M. Alcantar. 1995. Regression techniques and analytical solutions to demonstrate intrinsic bioremediation. In Intrinsic Bioremediation, ed. R.E. Hinchee, J.T. Wilson, and D.C. Downey, 109-116. Columbus, Ohio: Battelle Press.

Chapelle, F.H. 1994. Assessing the efficiency of intrinsic bioremediation. EPA/540/R-94/515. Washington, D.C.: U.S. Environmental Protection Agency.

Chiang, C.Y., J.P. Salanitro, E.Y. Chai, J.D. Colthart, and C.L. Klein. 1989. Aerobic biodegradation of benzene, toluene, and xylene in a sandy aquifer: Data analysis and computer modeling. Ground Water 27, no. 6: 823-834.

Cline, P.V., J.J. Delfino, and P.S.C. Rao. 1991. Partitioning of aromatic constituents into water from gasoline and other complex solvent mixtures. Water Resources Research 16, no. 1: 217-223.

Cozzarelli, I.M., R.P. Eganhouse, and M.J. Baedecker. 1990. Transformation of monoaromatic hydrocarbons to organic acids in anoxic groundwater environment. Environ. Geol. Water Science 16, 135-141.

Cozzarelli, I.M., M.J. Baedecker, R.P. Eganhouse, and D.F. Goerlitz. 1994. The geochemical evolution of low-molecular-weight organic acids derived from the degradation of petroleum contaminants in groundwater. Geochimica et Cosmochimica Acta 58, no. 2: 863-877.

Davis, J.W., N.J. Klier, and Carpenter. 1994. Natural biological attenuation of benzene in groundwater beneath a manufacturing facility. Ground Water 32, no. 2: 215-226.

Domenico, P.A., and F.W. Schwartz. 1990. Physical and chemical hydrogeology. New York: John Wiley \& Sons.

Edwards, E.A., and D. Grbic-Galic. 1992. Complete mineralization of benzene by aquifer microorganisms under 
strictly anaerobic conditions. Applied and Environmental Microbiology 58, 2663-2666.

Edwards, E.A., L.E. Wells, M. Reinhard, and D. Grbic-Galic. 1992. Anaerobic degradation of toluene and xylene by aquifer microorganisms under sulfate-reducing conditions. $A p$ plied and Environmental Microbiology 58, 794-800.

Evans, P.J., D.T. Mang, and L.Y. Young. 1991a. Degradation of toluene and $\mathrm{m}$-xylene and transformation of o-xylene by denitrifying enrichment cultures. Applied and Environmental Microbiology 57, 450-454.

Evans, P.J., D.T. Mang, K.S. Kim, and L.Y. Young. 1991b. Anaerobic degradation of toluene by a denitrifying bacterium. Appl. Environ. Microbiol. 57, 1139-1145.

Jamison, V.W., R.L. Raymond, and J.O. Hudson Jr. 1975. Biodegradation of high-octane gasoline in groundwater. Developments in Industrial Microbiology 16, 305-312.

Leahy, J.G., and R.R. Colewell. 1990. Microbial degradation of hydrocarbons in the environment. Microbiological Reviews 53, no. 3: 305-315.

Lee, M.D. 1988. Biorestoration of aquifers contaminated with organic compounds. CRC Critical Reviews in Environmental Control 18, no. 1: 29-89.

Lovley, D.R., J.D. Coates, J.C. Woodward, and E.J.P. Phillips. 1995. Benzene oxidation coupled to sulfate reduction. $A p$ plied and Environmental Microbiology 61, no. 3: 953-958.

MacIntyre, W.G., M. Boggs, C.P. Antworth, and T.B. Stauffer. 1993. Degradation kinetics of aromatic organic solutes introduced into a heterogeneous aquifer. Water Resources Research 29, no. 12: 4045-4051.

National Research Council. 1993. In situ bioremediation: When does it work? Washington, D.C.: National Academy Press.

Smith, J.H., J.C. Harper, and H. Jaber. 1981. Analysis and environmental fate of Air Force distillate and high density fuels. Report No. ESL-TR-81-54. Tyndall Air Force Base, Florida: Engineering and Services Laboratory.

Stauffer, T.B., T.B. Antworth, J.M. Boggs, and W.G. MacIntyre. 1994. A natural gradient tracer experiment in a heterogeneous aquifer with measured in situ biodegradation rates: A case for natural attenuation. EPA/540/R-94/515. Washington, D.C.: U.S. Environmental Protection Agency.

Thierrin, J., G.B. Davis, C. Barker, B.M. Patterson, F. Pribac, T.R. Power, and M. Lambert. 1993. Natural degradation rates of BTEX compounds and naphthalene in a sulfatereducing groundwater environment. Hydrological Sciences Journal 38, no. 4: 309-322.

Wiedemeier, T.H., J.T. Wilson, D.H. Kampbell, R.N. Miller, and J.E. Hansen. 1995a. Technical protocol for implementing intrinsic remediation with long-term monitoring for natural attenuation of fuel contamination dissolved in groundwater. San Antonio, Texas: Air Force Center for Environmental Excellence.

Wiedemeier, T.H., M.A. Swanson, J.T. Wilson, D.H. Kampbell, R.N. Miller, and J.E. Hansen. 1995b. Patterns of intrinsic bioremediation at two United States Air Force bases. In Intrinsic bioremediation, ed. R.E. Hinchee, J.T. Wilson, and D.C. Downey, 31-51. Columbus, Ohio: Battelle Press.

Wiedemeier, T.H., R.N. Miller, J.T. Wilson, and D.H. Kampbell. 1995c. Significance of anaerobic processes for the intrinsic bioremediation of fuel hydrocarbons. In Proceedings of the conference on petroleum hydrocarbons and organic chemicals in ground water: Prevention, detection, and restoration, 49-61, by National Ground Water Association. Dublin, Ohio: NGWA.

Wilson, B.H., G.B. Smith, and J.F. Rees. 1986. Biotransformations of selected alkylbenzenes and halogenated aliphatic hydrocarbons in methanogenic aquifer material: A micro- cosm study. Environmental Science and Technology 20, 997-1002.

Wilson, B.H., J.T. Wilson, D.H. Kampbell, B.E. Bledsoe, and J.M. Armstrong. 1990. Biotransformation of monoaromatic and chlorinated hydrocarbons at an aviation gasoline spill site. Geomicrobiology Journal 8, 225-240.

Wilson, J.T., D.H. Kampbell, and J. Armstrong. 1993. Natural biodegradation of alkylbenzenes (BTEX) from a gasoline spill in methanogenic groundwater. In Hydrocarbon bioremediation, ed. R.E. Hinchee, B.C. Alleman, R.E. Hoeppel, and R.N. Miller, 201-218. Boca Raton, Florida: Lewis Publishers.

Wilson, J.T., F.M. Pfeffer, J.W. Weaver, D.H. Kampbell, T.H. Wiedemeier, J.E. Hansen, and R.N. Miller. 1994. Intrinsic bioremediation of JP-4 jet fuel. EPA/540/R-94/515. Washington, D.C.: U.S. Environmental Protection Agency.

Young, L.Y. 1984. Anaerobic degradation of aromatic compounds. In Microbial degradation of aromatic compounds, ed. D.R. Gibson, 487-523. New York: Marcel-Dekker.

\section{Biographical Sketches}

ToddH. Wiedemeier is an associate with Parsons Engineering Science Inc. (1700 Broadway, Ste. 900, Denver, CO 80290). His research and professional interests include contaminant transport modeling and in situ remediation methods for contaminated soils and ground water. He holds a B.S. degree in geology from Colorado State University and an M.S. degree in geology from Wichita State University.

Matthew A. Swanson is a hydrogeologist and site manager with Parsons Engineering Science Inc. (1700 Broadway, Ste. 900, Denver, CO 80290). He holds a B.S. degree in geology from Trinity University and an M.S. degree in hydrogeology from the University of Wisconsin-Madison.

Dr. John T. Wilson is a senior research microbiologist with the U.S. EPA at the National Risk Management Research Laboratory ( 919 Kerr Laboratory Dr., Ada, OK 74820). Dr. Wilson's current research efforts involve the study of microbial processes that determine the fate and transport of organic contaminants in the subsurface environment. He has 12 years experience in site characterization, process definition, and modeling of intrinsic bioremediation. He received a Ph.D. in microbiology from Cornell University.

Dr. Donald Kampbell is a senior research chemist with the U.S. EPA at the National Risk Management Research Laboratory (919 Kerr Laboratory Dr., Ada, OK 74820). His current research efforts involve field monitoring techniques and field bioremediation process performance. He received a Ph.D. in agricultural chemistry from the University of Missouri. He is a licensed Professional Engineer.

Lt. Col. Ross N. Miller is currently assigned to Hill Air Force Base. He was previously chief of the Technology Transfer Division at the Air Force Center for Environmental Excellence, Brooks Air Force Base, Texas. He has extensive civil engineering experience and has served as a base bioenvironmental engineer at Cannon AFB, New Mexico, and Hill AFB, Utah. He holds B.S. and Ph.D. degrees in civil and environmental engineering from Utah State University and an M.S. degree in public health from the University of Utah. He is licensed Professional Engineer and Land Surveyor, and a Board Certified Industrial Hygienist.

Jerry E. Hansen is a project manager with the Air Force for Environmental Excellence (AFCEE) at Brooks Air Force Base, Texas. He currently is managing AFCEE's efforts at more than 40 air force bases across the country. He holds a B.S. degree in mechanical engineering from the University of Nebraska and an M.S. degree in aeronautical engineering from the University of Texas, Austin. 